Nig. J. Anim. Prod. 2017, 44(3):314 - 324

(C) Nigerian Society for Animal Production

Nigerian Journal of Animal Production

\title{
Nutrient retention, haematology and serum biochemistry of cockerels fed graded levels of cassava (Manihot esculenta) grit supplemented with moringa (Moringa oleifera) leaf meal
}

Okosun, S. E. and Eguaoje, S. A.

Department of Animal Science, Faculty of Agriculture, Ambrose Alli University, Ekpoma, Edo State, Nigeria

Corresponding author: eguaojeabiodunstanley@gmail.com; +2347031677645, 08162931998

\begin{abstract}
A sixteen week trial was conducted to assess the effect of replacing cassava grit supplemented with Moringa leaf meal (MLM) for maize on the nutrient retention, haematology and serum biochemistry of 120 "day old" Harco cockerel chickens. Four experimental cockerel starter and finisher diets were formulated with diet 1 formulated to contain $0 \%$ cassava grit while diet 2, 3 and 4 were formulated to contain cassava grit at 33.3, 66.6 and 100\% replacement for maize with 5\% of moring a leaf meal inclusion in diets 2, 3 and 4 respectively. Chicks were randomly assigned to the four treatment diets in a completely randomized designed (CRD). Result on nutrient digestibility show that crude fibre was significantly $(P<0.05)$ affected by the treatment diets with highest values of 68.21 recorded in birds fed diet 4 . Ash and NFE were significantly $(P<0.05)$ influenced by the treatment diets with highest mean values $(50.81$ and 55.15) observed in birds placed on 100\% CGM. Haematological indices revealed that Packed Cell Volume was significantly $(P<0.05)$ highest $32.17 \%$ among birds fed the control diet. However, neutrophil was significantly $(P<0.05)$ affected by the treatment diets with highest value $17.67 \%$ recorded in birds fed the control diet. Serological study revealed that Albumin value was significantly $(P<0.05)$ influenced by the dietary treatments with highest value $(1.60 \mathrm{mg} / \mathrm{dl})$ recorded among birds fed 33.3\% CGM based diet. Therefore, Cassava grit can replace maize up to $66.6 \%$ inclusion level with $5 \%$ appropriate supplementation with moringa leaf meal in cockerel diet for optimum nutrient utilization and blood quality.
\end{abstract}

Keywords: Cockerel, cassava grit, Moringa leaf meal, digestibility, blood indices

\section{Introduction}

Cockerel as a class of chicken has being neglected for too long in the pullet operation enterprise and this raises a great deal of concern to its survivability and acceptability. It has the ability to thrive on Agro waste and high fibrous feed stuff (Okosun and Ehebha, 2015) and this has really stimulated a lot of interest on them. Poultry diet consist mostly of cereals and legumes, and these feed sources like maize and sorghum, soya bean meal and groundnut meal are expensive and constitute about $50-55 \%$ of the formulated poultry diet; their productivity is low in Nigeria which means it does not meet national demand (Agbede et al, 2002; Hamzat et al, 2003; Okereke et al, 2006) so the need for intensification of search for cheaper alternatives that would support commensurate performance of this class of bird is inevitable (Egbewande, 2008). Effort has also been geared towards the utilization of relatively cheaper and available root and tubers in recent years.

Cassava (Manihot Spp) which contain a fibrous peel (10-15\% of tuber weight) and a core, the main region for starch (IITA, 1990) has a higher metabolizable energy of $(3,870 \mathrm{kca} / \mathrm{kg} \mathrm{ME})$ compare to maize with (3430kcal/kg ME), (Tion and Adeka, 2000). Cassava products have been used in feeding 
livestocks (Balogopalan, 2002; Nwokoro and Ekhosueni, 2006; Babatunde, 2013). However, the low protein content (Salcedo et al., 2010) and the dustiness of the feed (Ukachukwu, 2005; Ojewola et al., 2006; Kana et al., 2015) are among the limiting factor in cassava utilization. Many processing methods that have been used to enhance the feeding value of cassava include sundrying (Akinfola et al., 2007), parboiling (Salami and Odunsi, 2003). These methods have however achieved different levels of success. Utilization of cassava mill with its peel at the same time will reduce environmental pollution (Devendra, 1992) as well as eliminate wastages in cassava production and processing. Cassava grit is a product of processing of cassava tuber with its peels. Recently there has been interest in the utilization of Moringa (Moringa oleifera) commonly called Horse radish tree or drum stick tree, as a protein source for livestock (Makker and Becker, 1997; Sarwatt et al., 2002). Moringa leaves have quality attributes that makes it a potential replacement for Soyabean meal or fish meal in non-ruminant diet. Supplementing Moringa leaf meal with cassava grit could be a game changer in the poultry industry because apart from augmenting the amino acid profile of cassava, moringa also has some phytobiotic properties that aid in increasing the blood quality of the birds, it also possesses anti oxidants properties which are known to suppress formation of reactive oxygen species (ROS) and free radicals (Sofidiya et al., 2006; Ogbunugafor et al., 2011). Moringa oleifera was reported to be a good source of vitamin and amino acid (Olugbemi et al., 2010), it boost the immune system (Jayavardhanan et al., 1994). It also contains some antibacterial properties that make it serve as a phyto-therapeutic agent to combat infectious diseases (Patel, 2011). However, there is paucity of information on utilization of cassava grit with moringa leaf meal in cockerel diet. This study was therefore embarked upon to investigate the Nutrient utilization, haematology and serum biochemical indices of cockerel fed graded levels of cassava grit supplemented with moringa leaf meal.

\section{Materials and methods}

The experiment was carried out at the poultry unit of the livestock section, Teaching and Research Farm, Ambrose Alli University, Ekpoma for a period of sixteen (16) weeks. Cassava for the feeding trial was purchased from a reputable farm in Ekpoma Esan West Local Government Area of Edo State. The woody part was chopped off, and the cassava was thoroughly washed to reduce the silica level to near zero. It was then grated without peeling screw pressed for about 48 hours to reduce the hydrogen cyanide level to the barest minimum. It was mixed with palm oil to further encapsulate the cyanide in the milled cassava. It was thereafter fried, air dried and bagged into product known as the Cassava grit which was used in formulating the experimental diets. The moringa leaf meal was air-dried at room temperature for about 6-7 days until it breaks with a crispy feel, it was then stored dried green.

In a complete randomized design, one hundred and twenty day old black harco cockerels were divided into four groups of thirty chicks containing three replicates of ten chicks each. The replicates were housed in floor pens measuring $2.4 \mathrm{~m}^{2}$ with the floor covered with wood shavings as liter material. A plastic trough feeder and drinker were provided in each pen. The birds were vaccinated against Gumboro at 2 and 4 weeks, Newcastle at 3 and 5 weeks, fowl cholera at 6 weeks and fowl pox disease at 9 


\section{Okosun and Eguaoje}

weeks of age respectively. Four isonitrogenous and isocaloric diets $(1,2,3$ and 4 ) were formulated to contain $21 \%$ and $18 \%$ crude protein with 2650 and $2250 \mathrm{kcal} / \mathrm{kg}$ energy respectively in the chicks and grower mashes respectively (Tables 1 and 2). Cassava grit was included in both the chick and grower mashes at 0.00, $33.30,66.60$ and $100 \%$ replacement of maize in diets 1 (control), 2, 3 and 4 respectively while moringa leaf meal (MOLM) after grinding was included at 5\% level in all the treatment diets except the control diet. The feed and clean drinking water were provided ad-libitum throughout the 16 weeks of the experiment. The chick mash was fed for 8 weeks of age and the finisher mash for the remaining 8 weeks of the experiment.

The proximate composition of Cassava grit was analyzed based on the procedures described by AOAC, (2000). At the end of the $16^{\text {th }}$ week, two birds from each replicate were randomly selected and housed individually in a metabolic cage. A 5-day acclimatization period was allowed prior to a 4-day collection period; during which the birds were fed the specific quantities of the treatment diets. Daily excreta voided per bird was dried over night at $60^{\circ} \mathrm{C}$ for 12 hours and kept frozen $\left(-20^{\circ} \mathrm{C}\right)$ until it's ready for analysis. Prior to analysis, excreta sample was dried at $65^{\circ} \mathrm{C}$ in an air-tight oven to a constant weight and ground through a $1 \mathrm{~mm}$ screen for proximate analysis. Ground fed feed and voided faecal samples were analyzed for their respective proximate constituent according to the procedure outlined by AOAC (1990). Apparent digestibility of dry matter, crude protein, crude fibre, ether extract, ash and Nitrogen free extract were estimated respectively.

For haematology and serum biochemical indices, blood samples were collected through wing veins from the overnight fasted birds per treatment at the $16^{\text {th }}$ week. A set of samples were collected into sterilized tube containing ethylene diamine tetraacetic acid (EDTA) labeled bottle for Haematological studies while another set of blood samples were collected from the same birds into heparinised tubes for plasma chemistry determination. Packed cell volume (PCV) red blood cell (RBC), while blood cell (WBC) and haemoglobin $(\mathrm{Hb})$ were determined using improved Neubar's haemaetometer after dilution, and cyanomethamoglobin methods respectively as described by Dacie and Lewis (1991). Mean corpuscular volume (MCV), Mean corpuscular haemoglobin $(\mathrm{MCH})$, Mean corpuscular haemoglobin concentration (MCHC) as well as serum metabolites such as total protein, albumin, creatinine, and urea were determined by the method of Hyduke (1975), while globulin was estimated by the subtraction of albumin value from serum total protein value (Dacie and Lewis, 1991). All the data collected were subjected to analysis of variance (ANOVA) and differences between means treatments were determined using Duncan's multiple range test (DMRT) at 5\% level of probability. All statistical procedures were according to (Steel and Torrie, 1990) with the aid of SAS (1999) package.

\section{Results}

The analyzed nutrient composition of cassava grit (CG) and moringa leaf meal are shown in Table 3. Cassava grit had $88.03 \%$ Dry matter (DM), 3,402kcal/kg metabolizable energy $\mathrm{ME}, 2.05 \%$ crude protein (CP), 3.85\% crude fibre (CF), $2.32 \%$ ether extract (EE), 1.24\% ash and $78.57 \%$ nitrogen free extract (NFE). While moringa leaf meal had $94.60 \%$ Dry matter (DM), $28.00 \%$ crude protein (CP), $7.10 \%$ crude fibre (CF), 5.90\% ether extract (EE), $12.20 \%$ ash and $46.80 \%$ nitrogen free extract (NFE). 
Cockerels fed graded levels of cassava (Manihot esculenta) grit supplemented with moringa (Moringa oleifera) leaf meal

Table 1: Percentage compositions of cockerel starter diets

\begin{tabular}{lcccc}
\hline Ingredients & CGM $_{\mathbf{1}}$ & CGM $_{\mathbf{2}}$ & $\begin{array}{c}\text { CGM }_{\mathbf{3}} \\
\text { Levels }\end{array}$ & CGM $_{\mathbf{4}}$ \\
\cline { 2 - 5 } & $\mathbf{0}$ & $\mathbf{3 3 . 3}$ & $\mathbf{6 6 . 6}$ & $\mathbf{1 0 0}$ \\
\hline Maize & 40.71 & 27.13 & 13.75 & 0.00 \\
Cassava grit & 0.00 & 13.75 & 27.14 & 40.71 \\
Soya bean meal & 29.84 & 32.84 & 36.33 & 36.33 \\
Moringa leaf meal & 0.00 & 5.00 & 5.00 & 5.00 \\
Fish meal & 0.50 & 0.50 & 0.50 & 0.50 \\
Wheat offal & 25.72 & 19.35 & 16.66 & 13.88 \\
DCP & 2.00 & 2.00 & 2.00 & 2.00 \\
Limestone & 1.20 & 1.99 & 1.49 & 0.96 \\
Premix & 0.32 & 0.32 & 0.32 & 0.32 \\
Salt & 0.30 & 0.30 & 0.30 & 0.30 \\
Total & 100.00 & 100.00 & 100.00 & 100.00 \\
Calculated analysis & & & & \\
Crude protein & 21.00 & 21.00 & 21.00 & 21.00 \\
ME(Kcal/Kg) & 2650 & 2650 & 2650 & 2650 \\
\hline DCP: Dicalcium phosphate & & & &
\end{tabular}

Table 2: Percentage compositions of cockerel finisher diets

\begin{tabular}{lcccc}
\hline Ingredients & CGM $_{1}$ & CGM $_{\mathbf{2}}$ & $\begin{array}{c}\mathbf{C G M}_{3} \\
\text { Levels }\end{array}$ & CGM \\
\cline { 2 - 5 } & $\mathbf{0}$ & $\mathbf{3 3 . 3}$ & $\mathbf{6 6 . 6}$ & $\mathbf{1 0 0}$ \\
\hline Maize & 22.53 & 15.02 & 7.51 & 0.00 \\
Cassava grit & 0.00 & 7.51 & 15.02 & 22.53 \\
Soya bean meal & 16.45 & 16.94 & 16.94 & 18.06 \\
Moringa leaf meal & 5.00 & 5.00 & 5.00 & 5.00 \\
Palm oil & 0.00 & 0.00 & 0.00 & 0.09 \\
Wheat offal & 50.01 & 50.05 & 50.57 & 50.54 \\
DCP & 1.50 & 1.50 & 1.50 & 1.50 \\
Limestone & 3.78 & 3.64 & 2.85 & 1.66 \\
Premix & 0.30 & 0.30 & 0.30 & 0.30 \\
Salt & 0.32 & 0.32 & 0.32 & 0.32 \\
Total & 100.00 & 100.00 & 100.00 & 100.00 \\
Calculated analysis & & & & \\
Crude protein & 18.00 & 18.00 & 18.00 & 18.00 \\
ME (Kcal/Kg) & 2250 & 2250 & 2250 & 2250 \\
\hline
\end{tabular}

Table 3: Analyzed nutrient composition of cassava grit and moringa leaf meal

\begin{tabular}{lcc}
\hline Nutrients (\%) & Cassava grit & Moringa leaf meal \\
\hline Dry matter & 88.03 & 94.60 \\
Crude protein & 2.05 & 28.00 \\
Crude fibre & 3.85 & 7.10 \\
Ether extract & 2.32 & 5.90 \\
Crude ash & 1.24 & 12.20 \\
Nitrogen free extract & 78.57 & 41.40 \\
ME(Kcal/Kg) & 3050 & 3175 \\
\hline
\end{tabular}

*Metabolizable energy value was calculated using the method 37x \% CP $+81 x \%$ EE $+35.5 x$ \%FE for poultry (Fisher and Boorman, 1986) 


\section{Okosun and Eguaoje}

Apparent nutrient digestibility of cockerel fed varying levels of cassava grit with moringa leaf meal

Table 4 revealed that the dietary treatments has no significant $(\mathrm{P}>0.05)$ effect on the apparent digestible dry matter with highest value of $69.00 \%$ in birds fed 66\% CGM and least in diet 4 with mean value of $67.80 \%$. Digestible crude protein also had similar $(\mathrm{P}>0.05)$ values highest $56.54 \%$ recorded in birds fed the control diet and least value of $49.60 \%$ in birds placed on diet 2 . Apparent digestible crude fibre showed a significant $(\mathrm{P}<0.05)$ variation among birds fed treatment diets with highest value of $68.21 \%$ recorded in birds fed diet 4 , similar to $60.04 \%$ in control diet and lowest $58.64 \%$ in birds fed diet 3. Apparent digestible ether extract was similar $(\mathrm{P}>0.05)$ with highest mean value of $50.97 \%$ recorded among birds fed diet 2 , followed by control $(50.77 \%)$ and least value of $41.25 \%$ in birds fed diet 4 . Digestible Ash and Nitrogen Free Extract (NFE) were significantly $(\mathrm{P}<0.05)$ highest in birds fed $100 \%$ CGM diet with mean values of 50,81 and $55.15 \%$ and lowest in $\operatorname{diet} 3$ with values of 42,91 and $43.17 \%$ respectively.

Table 4 : Apparent nutrient digestibility of cockerel fed varying levels of cassava grit with moringa leaf meal

\begin{tabular}{lccccc}
\hline & \multicolumn{3}{c}{ Inclusion levels of CGM (\%) } \\
& \multicolumn{1}{c}{$\mathbf{0}$} & $\mathbf{3 3 . 3}$ & $\mathbf{6 6 . 6}$ & $\mathbf{1 0 0}$ \\
\cline { 2 - 6 } Parameters & \multicolumn{1}{c}{ Diets } & \multicolumn{3}{c}{ SEM \pm} \\
\hline Apparent digestible dry matter & 68.10 & 68.30 & 69.00 & 67.80 & 14.30 \\
Apparent digestible crude protein & $56.54^{\mathrm{ab}}$ & 49.60 & 54.57 & 56.09 & 4.14 \\
Apparent digestible crude fibre & 60.04 & $59.93^{\mathrm{b}}$ & $58.64^{\mathrm{b}}$ & $68.21^{\mathrm{a}}$ & 3.50 \\
Apparent digestible ether extract & 50.77 & 50.97 & 46.48 & 41.15 & 7.24 \\
Apparent digestible ash & $48.55^{\mathrm{a}}$ & $48.84^{\mathrm{a}}$ & $42.91^{\mathrm{b}}$ & $50.81^{\mathrm{a}}$ & 1.27 \\
Apparent digestible NFE & $49.15^{\mathrm{ab}}$ & $43.24^{\mathrm{b}}$ & $43.17^{\mathrm{b}}$ & $55.15^{\mathrm{a}}$ & 4.52 \\
\hline
\end{tabular}

$a b c$ : means in the same row with varying super script differ significantly $(P>0.05)$

SEM+: standard error of mean

CGM. Cassava Grit Moringa supplement

Haemotological indices of cockerel fed varying levels of cassava grit with moringa leaf meal supplementation

Haematological parameters of Cockerel chickens as influenced by the Dietary treatments Table 5 revealed that traits like Haemoglobin (Hb), Red blood cell (RBC), Mean corpuscular volume (MCV), Mean corpuscular haemoglobin $(\mathrm{MCH})$, Mean corpuscular haemoglobin concentration (MCHC) and Lymphocyte were not significantly $(\mathrm{P}>0.05)$ influenced by the dietary treatment. However, Packed cell volume (PCV), platelet, white blood cell and Neutrophil were significantly $(\mathrm{P}<0.05)$ influenced by the treatment diets. Packed cell volume was highest $(\mathrm{P}<0.05)$ in birds fed $0 \%$ CGM with mean value of $32.17 \%$ followed by a similar statistical value $31.03 \%$ in birds fed 66.6\% CGM and lowest $24.67 \%$ in birds fed 25\% CGM. Platelet was also significantly $(\mathrm{P}<0.05)$ highest in birds fed $66 \%$ GCM with a mean value of $\left(52.33 \times 10^{3} /_{\mathrm{ml}}{ }^{3}\right)$, followed by $\left(40.67 \times 10^{3} /_{\mathrm{ml}}{ }^{3}\right)$ in birds fed 100\% CGM and least $\left(23.67 \times 10^{3} \%_{\mathrm{ml}}^{3}\right)$ in birds fed the control diet. White blood cell was significantly $(\mathrm{P}<0.05)$ highest in birds fed the control with value $\left(65.70 \times 10^{3} /{ }_{\mathrm{ml}}^{3}\right)$, followed by (52.33 and $\left.42.33 \times 10^{3} \%_{\mathrm{ml}}^{3}\right)$ in birds placed on diet 2 and 4 respectively while lowest value of $(21.00$ $\left.\mathrm{x} 10^{3} /_{\mathrm{ml}}{ }^{3}\right)$. Neutrophil was significantly $(\mathrm{P}<0.05)$ highest $17.67 \%$ in birds fed the 
control diet similar to $11.20 \%$ in diet 2 while least comparable values 8.63 and $7.63 \%$ were recorded among birds fed diet 3 and 4 respectively.

Table 5: Haemotological Indices of Cockerel Fed varying levels of cassava grit with mo ringa leaf meal supplementation

\begin{tabular}{|c|c|c|c|c|c|}
\hline \multirow[b]{4}{*}{ Parameters } & \multicolumn{4}{|c|}{ Inclusion levels of CGM (\%) } & \multirow{4}{*}{ SEM \pm} \\
\hline & $\mathbf{0}$ & 33.3 & 66.6 & 100 & \\
\hline & \multicolumn{4}{|c|}{ Diets } & \\
\hline & 1 & 2 & 3 & 4 & \\
\hline Haemoglobin $(\mathrm{g} / \mathrm{dl})$ & 9.77 & 8.10 & 9.70 & 8.73 & 0.65 \\
\hline Packed cell volume (\%) & $32.17^{\mathrm{a}}$ & $24.67^{\mathrm{ab}}$ & $31.03^{\mathrm{a}}$ & $28.97^{b}$ & 2.32 \\
\hline Red blood cell (x 106/ml) & 2.19 & 1.96 & 2.19 & 1.88 & 0.16 \\
\hline Mean corpuscular volume (fl) & 151.4 & 144.30 & 144.70 & 153.6 & 3.86 \\
\hline Mean corpuscular Haem. (Pg) & 40.17 & 42.47 & 43.80 & 44.83 & 3.27 \\
\hline Mean corp. Haem. Conc. (Pg) & 31.67 & 30.07 & 30.73 & 44.83 & 3.27 \\
\hline Platelet $\left(\times 10^{3} / \mathrm{ml}^{3}\right)$ & $23.67^{\mathrm{c}}$ & $30.67^{\mathrm{bc}}$ & $52.33^{\mathrm{a}}$ & $40.67^{b}$ & 15.15 \\
\hline White blood cell $\left(\times 10^{3} / \mathrm{ml}^{3}\right)$ & $65.70^{\mathrm{c}}$ & $52.33^{\mathrm{b}}$ & $21.00^{\mathrm{c}}$ & $42.33^{\mathrm{bc}}$ & 15.20 \\
\hline Neutrophil (\%) & $17.67^{\mathrm{a}}$ & $11.20^{\mathrm{ab}}$ & $8.63^{b}$ & $7.63^{\mathrm{b}}$ & 3.21 \\
\hline Lymphocyte (\%) & 71.27 & 76.17 & 83.80 & 83.73 & 4.96 \\
\hline
\end{tabular}

$a b c$ : means in the same row with varying super script differ significantly $(\mathrm{P}<0.05)$,

SEM+: standard error of mean

CGM: Cassava grit Moringa supplement

Serum biochemistry of cockerel fed varying levels of cassava grit with moringa leaf meal supplementation

Serological studies of cockerel finisher as influenced by the dietary treatment (Table 6) revealed that Total protein, Globulin, urea and creatinine were not significantly $(\mathrm{P}>0.05)$ influenced by the dietary treatments. However, significant $(\mathrm{P}<0.05)$ variation was observed in the albumin values. Total protein was highest at the $33.3 \%$ CGM supplementation with mean value of $4.10 \mathrm{mg} / \mathrm{dl}$ in birds fed $33.3 \%$ CGM, followed by $3.47 \mathrm{mg} / \mathrm{dl}$ among birds placed on $66.6 \%$ CGM, while least value of $3.23 \mathrm{mg} / \mathrm{dl}$ was recorded among birds fed $100 \%$ CGM. Albumin was significantly $(\mathrm{P}<0.05)$ influenced by the dietary treatment with highest value of $1.60 \mathrm{mg} / \mathrm{dl}$ was recorded among birds placed on $33.3 \%$ CGM, followed by $1.53 \mathrm{mg} / \mathrm{dl}$ among birds fed the control diet and lowest value of $1.43 \mathrm{mg} / \mathrm{dl}$ was recorded among birds fed $100 \%$ CGM. Globulin value was similar $(\mathrm{P}>0.05)$ with highest mean value of
$2.50 \mathrm{~g} / \mathrm{dl}$ among birds fed diet 2 , followed by $1.97 \mathrm{~g} / \mathrm{dl}$ in diet 3 and least value of $1.80 \mathrm{~g} / \mathrm{dl}$ in birds fed diet 4 . Urea was statistically similar $(\mathrm{P}>\mathrm{O} . \mathrm{O} 5)$ with highest values of 3.77 and $3.77 \mathrm{~g} / \mathrm{dl}$ recorded among birds fed diets 1 and 4 while least comparable values of 3.33 and $3.33 \mathrm{~g} / \mathrm{dl}$ were recorded among birds placed on diets 2 and 3 respectively. Creatinine value was lowest in birds fed $33.3 \%$ CGM with mean value of $0.47 \mathrm{~g} / \mathrm{dl}$ while equal values of $0.53,0.53$ and $0.53 \mathrm{~g} / \mathrm{dl}$ were recorded from birds fed diet 1, 3 and 4 respectively with a mean standard error of 0.07 .

\section{Discussion}

The highest digestible dry matter value obtained among birds fed 66.6\% CGM could be due to the quality of the nutrient composed in this test diet and this is a pointer to the fact that the test diet are of high quality. This negates the report of Ngiki et al. (2014) who reported significant $(\mathrm{P}<0.05)$ difference when broilers were fed Cassava Root-Leaf meal mixture as replacement for 


\section{Okosun and Eguaoje}

Table 6: serum biochemical indices of cockerel finisher fed varyi ng levels of cassava grit with moringa leaf meal supplementation

\begin{tabular}{lccccc}
\hline & \multicolumn{7}{c}{ Inclusion levels oF CGM (\%) } \\
& $\mathbf{0}$ & $\mathbf{3 3 . 3}$ & $\mathbf{6 6 . 6}$ & $\mathbf{1 0 0}$ \\
\cline { 2 - 6 } & \multicolumn{7}{c}{ Diets } & $\mathbf{4}$ & SEM \pm \\
Parameters & $\mathbf{1}$ & $\mathbf{2}$ & $\mathbf{3}$ & 3.23 & 0.36 \\
Total protein (mg/dl) & 3.46 & 4.10 & 3.47 & $1.43^{\mathrm{c}}$ & 0.05 \\
Albumin (mg/dl) & $1.53^{\mathrm{b}}$ & $1.60^{\mathrm{a}}$ & $1.50^{\mathrm{b}}$ & 1.80 & 0.35 \\
Globulin (g/dl) & 1.93 & 2.50 & 1.97 & 3.67 & 0.36 \\
Urea (g/dl) & 3.67 & 3.33 & 3.33 & 0.53 & 0.07 \\
Creatinine (g/dl) & 0.53 & 0.47 & 0.53 & & \\
\hline
\end{tabular}

$A b c$ : means in the same row with varying super script differ significantly $(p>0.05)$,

Sem+: standard error of mean

Cgm: cassava grit supplemented with moringa

maize. Apparent digestible crude protein values for all the dietary treatment were similar; this might perhaps be due to the cushioning effect of moringa leaf meal as an excellent plant protein source. This corroborates the findings of Ngiki et al., 2014. It also laid credence to the work done by Mukthar (2013) and Okosun and Oyedeji (2015) who reported that Moringa is an excellent plant protein source in Poultry feeding. The significantly lowest value observed for apparent crude fibre digestibility in birds fed $66.6 \%$ CGM could be adduced to the balanced ratio of the cassava grit-maize mixture in the formulated diet which in the long run optimizes the crude fibre level of the test diet. This lend support from the report of Ngiki et al.(2014) who observed similar value for digestible crude fibre for broilers fed Cassava Root-leaf meal mixture. The comparable values recorded in the apparent digestible ether extract of the birds fed the treatment diets could infer that the fact that the birds on these various treatment diets optimally utilize the fat component of the test diet. The similarity in the apparent digestible ash value could be due to the fact that birds on these diets maximally utilize the nutrient present in their diets. The higher Nitrogen Free Extract value at $100 \%$ CGM is obviously due to the high energy content of CGM which agrees with the report of Aderemi, (2007); while its similarities with the control that had no cassava grit clearly proves the calorific value similarity of maize and cassava grit.

The low haemoglobin value recorded in this study could be as a result of the residual cyanide in the cassava grit which must have had greater affinity for metals such as copper and iron and make them unavailable thereby reducing the haemoglobin count and hence effective oxygen transportation This is in agreement with the findings of Tewe,(1999) who reported that $40 \%$ whole cassava root meal fed to cockerel resulted in significantly lower haemoglobin value at the finisher phase. The significant variation in the Packed Cell Volume value with highest value in birds placed on $66.6 \%$ CGM comparable to the control revealed the fact that these feeds have better nutritional qualities and birds maintained on them had low susceptibility to infections compare to birds placed on diet 2 and 4 . The similarity in most of the haematological parameters assayed in this study could be due to the nutritional adequacy and safety of the test diet which agrees with the report of (Olabamiji, et al., 2007). The reduction in the values of neutrophil as inclusion of CGM increases showed that the anti nutrients that may be present in CGM did not affect the blood quality of the birds. The values for all 
the parameters falls with the recommended range establish by earlier researchers Maxwell, et al., (1990), (Mitruka and Rawnsley, 1997 and also with the report of Mohammed et al., 2008).

Total proteins are the most abundant compound of serum. The protein make up of an animal is of important diagnostic significance because they are involved in enzyme, hormones and antibodies synthesis and as a reserve source of nutrient for body tissues and muscles. The statistical similarity in the total protein value indicates that the quality of protein in the experimental diets was adequate and the consumption by birds did not result in stress, disease, starvation or malnutrition and this values recorded are within the optimum level reported by Rajurker (2009). The highest albumin and globulin values recorded in birds fed $33.3 \%$ CGM are traceable to the highest protein value recorded in the birds fed the same treatment diet. Serum protein, albumin and Globulin synthesis is related to the availability of protein and micronutrients (Hofferberg and Block, 1996). Serum urea is known to be a function of the protein quality ingested by the animal, energy deficiency and disease condition which impair protein utilization. When diet is deficient in essential amino acid, the amino acid present will be deaminated resulting to an increase in urea excretion (Ranyhon, 2001). In other words, the comparable Urea value recorded when Cassava Grit-Moringa leaf meal mixture was included in the diet could be due to the effective protein utilization of the birds placed on the treatment diets. Eggum (1970) reported that creatinine is an indirect measure of protein utilization in poultry birds. The low value and relative non significant differences observed in the Creatinine values of birds fed experimental diets in this study suggest favourable protein utilization as cassava grit/Moringa leaf meal supplement to replaced maize.

\section{Conclusion}

The result of the study revealed that Cassava grit at $66.6 \%$ replacement level with $5 \%$ moringa leaf meal incorporation for maize improves the Nutrient utilization and blood quality of cockerel chickens was best at $33.3 \%$ CGM replacement for maize. A practical ration of 33.3 to $66.6 \%$ cassava grit as major energy source with as low as $5 \%$ MOLM incorporated is therefore advocated for cockerel production.

\section{References}

A.O. A. C. 1990. Official Methods of Analysis. Association of official Analytical chemist, Washington DC, USA $15^{\text {th }}$ edition. 807-928.

Aderemi, F. A. 2007. Effect of replacement of wheat Bran with cassava root sievate supplemented or unsupplemented with Enzyme on the haematology and serum biochemistry of pullet chicks. Tropical Journal of Animal Science. 7, 147-153.

Agbede, J. O., Ajaja, K. Aletor, V. A. 2002. Influence of Roxazyme $G$. supplementation on the utilization of sorghym dust-based diet for broiler chick. proceedings of $27^{\text {th }}$ Annual conference of NASP. Akure, 105-108.

Akinfola, E. O., Matanmi, O. and Fatufe, A. A. 2007. Effect of residual cyanogenic glucosides in cassava based diets on serum metabolites of cockerel chicken. In Proceedings of $32^{\text {nd }}$ Annual Conference of the Nigeria Society for Animal Production. University of Calabar.Pp. 105107 


\section{Okosun and Eguaoje}

Babatunde, B. B. 2013. Effect of feeding cassava waste on the performance and meat quality of broiler chickens. Malaysia Journal of Animal Science. 16(2): 63-73.

Balogopalan, C. 2000. Integrated technologies for value addition and post-harvest management in tropical tuber crops.Central tuber crop research institute, $\mathrm{S} r$ e e $\mathrm{k}$ a $\mathrm{r}$ i y a $\mathrm{m}$, Thiruvanathapuram, Kerala, India.Pp:174

Dacie, J. V. and Lewis, S. N. 1991. Practical haematology $8^{\text {th }}$ edition Longman group Ltd. Pp 22-68

Ed. McGraw Hill Book Co. Inc. New York, USA.

Devendra, C. 1992. Non conventional feed resources in Asia and the pacific. Strategies for expanding utilization at the small Farm level. FAO-APHCA. Pp; 73-105

Egbewande, O. O. 2008. A survey on consumption of meat and meat products in Niger state, Nigeria. Nigeria Journal of Animal science, 12:175-183

Eggum, B. O. 1990. Protein metabolism in Farm animals. Evaluation, Digestion, Absorption and Metabolism. Oxford science Publications. Deutscher landwirtscafts verlag, berlin. Pp $1-25$

Hamzat, R. A., Timaiyu, A. K., Raji, A. M. 2003. Effect of dietary inclusion of cocoa pod Hussk (KPH) on growth performance of West African Dwarf (WAD) Goats. Proceedings of $28^{\text {th }}$ Annual conference of NASP, Ibadan Pp 271-273

Hyduke, R. R. 1995. Clinical
Biochemistry manual. The University of Iowa Medical technology Programme, Iowa City, USA.

Jayavardhanan, K. K., Suresh, K., $P$ a n ikk ar, K. R. a n d Vasuedevan, D. M. 1994. Modular potency of drumstick lectin on host defence system. In Journal of experimental clinical cancer Research. Vol 13, p. 427440

Kana, J. R., Doue, M., Kreman, K., Diarra, M., Mube, K. H., Ngouana, T. R. and Teguia, A. 2015. Effect of the rate of incorporation of sweet potato flour in the diet of broiler chickens on growth performances. Journal of Applied Biosciences, 91: 85398546

Maxwell, M. H., Robertson, G. W., Spence, S. and McCorquodute, C. C. 1990 . C o m paris m of haemotological value of restricted and ad Libitum feeding in domestic fowls, red blood characteristics. Brit.poult.sci.31(3): 407-413

Mitruka, B. M. and Rawnsley, H. M. 1977.

Clinical biochemical and haematological reference value in normal experimental animal. Masson publication company. USA Inc. New York.Pp:21-84

Mohammed, M. D., Abdalsalam, Y. I., Mohammed, A. R., Keir, W., Jiu-yu and Hussein, M. H. 2008. Growth performance and indigenous $\mathrm{X}$ exotic crosses of chicken and Evaluation of general and specific combining ability under sudan condition. International Journal of Poultry Science, 4:468-471.

Mukhtar, F. 2013. Effect of lactobacillus 
Cockerels fed graded levels of cassava (Manihot esculenta) grit supplemented with moringa (Moringa oleifera) leaf meal

culture as probiotic on blood parameters, plasma, enzymes activities and mortality of broilers chicken. Research journal of Animal Science, 7:7781.

Ngiki,Y. U., Igwebuike, J. U., Moruppa, S. M. 2014. Effect of replacing maize with cassava root-leaf meal mixture on the performance of broiler chickens.International Journal of Science and Technology.vol 3.p.285-296.

Nwokoro, S. O. and Ekhosuehi, H. T. 2006. Effect of maize with cassava peer in cockerel diet on performance and carcass characteristics. Tropical Animal and Production, 37:495-501

Ogbonugafo, H. A., Eneh, F. U., Ozumba, A. N., Igwo-Ezikpe and Okpuzor, 2011. Physio-chemical and antioxidant properties of moringa oleifera seed oil. Parkistan Journal of Nutrition.10: 409-414

Ojewole, G. S., Opara, O. E. and Ndupu, O. 2006. The substitution value of cassava meal, supplemented and unsupplemented with palm oil for maize in broiler diets. Journal of Animal and Veterinary Advances, 5(6): 478-482.

Okereke, C. O. Ukachukwu, S. N., Nsa, E. E. 2006. Potentials of cassava leaves and/or foliage in poultry. Proceeding of the $40^{\text {th }}$ annual conference of the Agricultural society of Nigeria, Umudike, 25:515-517

Okosun, S. E. and Oyedeji, J. O. 2016.Effects of feeding graded levels of Moringa oleifera leaf meal (MOLM) on the performance and blood biochemistry of broiler chicks. Nigerian Journal of Agriculture and Forestry (NJAF)

Okosun, S. E. and Ehebha, E. T. E. 2015 Effect of rice husk (RH) on the nutrient utilization and performance of cockerel chicks. Journal of Agricultural Research (TAJAR)

Olabamiji, J. M. Osikabor, B. O. O., Fumuyide, O. O. Adu, A. O., Adems, B. A., Baba Saya, M. B. 2007. Contribution of live stock to rural household food security in Ido Local Government Areas of Oyo State. The proceedings of $29^{\text {th }}$ congress of the Nigerian Society of Animal Production, March 21-25, 2007, Sokoto Nigeria.

Olugbemi, T. S. Mutayoba, S. K. and Kekule, F. P. 2010. Evaluation of moringa oleifera leaf meal inclusion in cassava chip based diets fed to laying birds. Livest. Research for rural development., 22 (6):118

Patel, J. P. 2011. Antibacterial activity of methanolic and acetone extract of some medicinal plants used in India folklore. International journal of phytomedicine, vol $3 \mathrm{p}, 261-269$.

S.A.S/STAT, 1999. SAS User's Guide: Statistic released version 8.0. Statistical Analysis.

Salcedo, A., Valle, A. D., Sanchez, B., Ocasio, V., ortiz, A., Marquez, P. and Siritunga, D. 2010 . Comparative evaluation of physiological post-harvest root deterioration of 25 cassava (Manihot esculenta) accessions: visual vs. hydroxycoumarins fluorescent accumulation analysis. African Journal of Agricultural Research, 5(22): 


\section{Okosun and Eguaoje}

$3138-3144$.

Sawartt, S. V., Milangha, S. M., Lukule, F. P., Madalla, N. 2002. Moringa oleifera and cotton seed cake as supplement for smallholder dairy cows fed Napier Grass .Livestock Research for rural development.16:38-42

Steel, R. G. D. and Torrie, J. H. 1990. Principles of Statistics. A Biometric Approach. $2^{\text {nd }}$

System Institute Incorporation Cary, NC.

Tewe, O. O. 1999. Detoxification of cassava products and effect of residual toxins on consuming animals. In Root tubers, Plantain and banana in animal feeding. (Editors; Manchin, D and Solving Nyvold).FAO. Animal Production and health paper No. 95:81-95
Tion, M. A. and Adeka, I. 2000. Evaluation of cassava root meal as a replacement for maize in broiler diet. Proceedings of the $25^{\text {th }}$ Annual NSAP conference.p 313116

Ukachukwu, S. N. 2005. Studies on the nutritive value of composite cassava pellets for poultry: chemical composition and metabolizable energy. Livestock Research for Rural Development, 17: article \#125. Retrieved March $1, \quad 2012, \quad \mathrm{f} \mathrm{r} \mathrm{o} \mathrm{m}$ http://www.lrrd.org/lrrd17/11/uk ac17125.htm

Yeoh, H. N. 1971. Cyanide content of cassava. Malaysia Agricultural Journal; 2 (5): 435-446.

Received: $7^{\text {th }}$ February, 2017 Accepted: $21^{\text {st }}$ June, 2017 